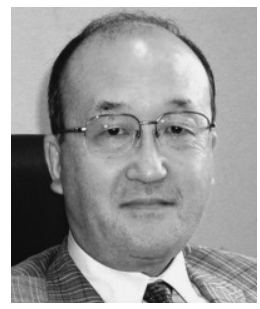

東海大学医学部基盤診療学系病理診断学 長村 義之

病理診断は、一般的には肉眼診断に続き的確な部分の顕微鏡標本作製を行い顕微鏡的に観察し最終診断を下す 手順を踏んでいる。顕微鏡診断の際に、最近では免疫組織化学および分子病理学的手法が応用され、予後、治 療指針などにかかわる情報も提供するよう努力がなされている。内分泌腫瘍の場合、ホルモン産生という他の 腫瘍にはない性格を有しているので、ホルモンの存在を免疫組織化学的に確認することも重要となる。また、 内分泌腫瘍のもうひとつの病理診断での特徴として、転移を特徵とする “予後推定が困難”という面が挙げら れよう。

外科的に摘出される内分泌腫場として以下の分野が含まれる。

1. 甲状腺 濾胞性腫瘍 濾胞腺腫 濾胞癌 乳頭癌 未分化癌 髄様癌

2. 膵臓 内分泌腫瘍 インスリノーマ グルカゴノーマ ガストリノーマなど

3. 消化管 内分泌腫瘍 カルチノイド ガストリノーマ など

4. 副腎 皮質腫瘍 皮質腺腫 皮質癌

髄質腫瘍＼cjkstart褐色細胞腫パラガングリオーマ

5. 副甲状腺 腺腫 過形成（一次性、二次性）癌

WHO でも2004年に内分泌腫瘍についての腫瘍分類が以下のように報告されている。

Well differentiated endocrine tumor(WDET) (汎用されているカルチノイドに相当する)

Well differentiated endocrine carcinoma(WDEC)（上記腫瘍で転移などのあるもの）

Poorly differentiated endocrine carcinoma(PDEC) small cell carcinoma

Mixed exocrine and endocrine carcinoma

この領域の腫瘍の多くがペプチドホルモンを産生するいわゆる“神経内分泌腫瘍”であるところから、neuroendocrine tumor(NET) という用語もしばしば用いられる。上記の分類においても、WDNET WDNEC PDNEC が頻用される。肺癌などでは、Large cell neuroendocrine carcinoma (LCNEC)などの名称もしばし ば登場する。予後としては、WDET は、 benign behavior あるいは uncertain behavior, WDEC では low grade malignant あるいは gross local invasion and/or metastasis の分類が WHO で推奨されている。また、遺伝 子変化の解析も進んできており、特定の腫瘍の遺伝的背景(家族性か否か)、予後、などについても明らかにす る必要がある。

また、消化管。膵臓における神経内分泌腫瘍(GEPNET と総称される)では、しばしば肝、リンパ節に転移す るが、その際に腫瘍細胞にソマトスタチン受容体(特に SSTR2a)が発現されている場合は、ソマトスタチンア ナローグ(Octreotide) の効果が期待できる。

本講演では、いくつかの代表的な腫瘍を例にとり、最近の内分泌腫瘍での病理学的アプローチを論じてみたい。 


\section{【履 歴】}

1970 年 慶應義塾大学医学部卒業

1970 年-73 年 米国 University of Colorado Medical Center 病理レジデント

1973 年 -74 年 同 リサーチフェロー

1974 年 -75 年 米国ミシガン州ヘンリーフォード病院 外科病理クリニカルフェロー

1975 年 -78 年 東海大学医学部病理学教室助手

1978 年 -83 年 東海大学医学部病理学教室講師

1983 年 -88 年 東海大学医学部病理学教室助教授

1988 年一東海大学医学基盤診療学系病理診断学教授

1996 年 -05 年 東海大学医学部副学部長

1996 年 -06 年 東海大学医学部医学科基盤診療学系 学系長

2006 年 -07 年 東海大学医学部附属病院 副院長

2007 年 -08 年 東海大学医学部大学院先端医科学専攻副主任

【学会役員 (現在)】

日本病理学会 理事長

日本組織細胞化学会 元理事長・現理事

日本臨床細胞学会 副理事長

日本内分泌学会 理事

日本内分泌病理学会 理事

国際病理アカデミー Vice President(Asia), IAP

国際細胞学会 Vice President, IAC

国際組織細胞化学会 President, IFSHC

The Histochemical Society (USA) Councilor (2002-2008)

【雑誌編集委員 (現在)】

Endocrine Pathology (Assoicate Editor)

Modern Pathology Cancer Cytopathology

Pathology International

J Histochemisty \& Cytochemistry (JHC) (Associate Editor)

Acta Histochem et Cytochem (AHC)

Pathology Research \& Practice

Acta Cytologica Diagnostic Cytopathology

Applied Immunochemistry\& Molecular Mophology (AIMM)

【主催学会 (会長)】

1994 年 内分泌病理学会 (Endocrine Pathology Society) 会長 (San Francisco)

2002 年 第 6 回日米合同組織細胞化学会議会長 (Seattle)

2002 年 第 6 回日本内分泌病理学会学術総会会長（東京）

2003 年 第21回内分泌代謝学サマーセミナー会長（箱根）

2005 年 第94回日本病理学会総会会長(パシフィコ横浜)

2006 年 第47回日本臨床細胞学会総会会長（パシフィコ横浜）

2007 年 第22回日本下垂体研究会学術集会会長（湘南国際村）

2009 年 第19回日本間脳下垂体腫瘍学会会長（東京ステーションコンファレンス） 


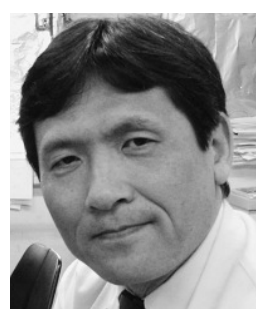

筑波大学大学院人間総合科学研究科 野口 雅之

1999年に WHO は肺腫瘍に関する組織分類（第 3 版）を改訂した。この分類で肺腺がんは 4 つの組織亜型（腺 房型、乳頭型、細気管支肺胞上皮型、粘液産生充実型）抢よびこれらの混合型に分類されている。一方、腺が んの分類とは異なるが肺腺がんの前浸潤病変として異型腺腫様過形成 (atypical adenomatous hyperplasia, AAH)が定義されている。日本肺癌学会の組織分類委員会は基礎研究、臨床研究の基盤としての病理組織分類 は国際分類で行うべきであるという観点から2003年に改訂された『肺癌取扱い規約 (第 6 版)』から日本独自で 定めてきた「肺がん組織分類」を廃止して肺がんの組織分類はすべてWHO の分類で行うこととした。この取 扱い規約では WHO 分類の詳しい解説を行っている。こうして日本ではWHO 分類が肺がんの組織分類とし て広く一般に用いられるようになった。WHO の改訂からほぼ10年がたち、この間に現行の肺腺がん組織分類 の良い点、悪い点が明らかになりつつある。その一つは現状では肺腺がんと診断される症例の 8 割以上は混合 型の肺腺がんと診断される。肺腺がんは極めてへテロな集団であるためである。このような偏った分類では正 確な生物学的分類とは言えない。また、特に問題が大きかった点は細気管支肺胞上皮型 (BAC) の扱いである。 BAC は既存の肺胞上皮を置換しながら増殖するタイプの腺がんで、定義によれば浸潤増殖をしていない腫瘍 ということになっている。しかし現行の分類では BAC はその他の浸潤癌である組織亜型と同じグループに分 類されている。また BAC は CT 検診等で特に日本で多く発見されるようになったが、BAC の予後が極めて良 好なためその他の腺がんの組織亜型と同列に分類することに不都合が多くなった。さらに歴史的に BAC とい うと肺炎型の径気腔転移を特徴とする予後の悪い variant を考える一般病理医、臨床医も多い。国際肺癌学会 の病理パネルは次回の WHO 分類改訂に向けて活動を開始したが、特に腺がんの分類の変更を行うための第 1 回目の国際会議を本年の 3 月に New York で行った。この会議では上記した不都合な点について病理医は勿 論の事、外科医、内科医、放射線医、基礎研究者も交えて活発な議論が行われた。その結果、BACという診断 名を廃止し、pure BAC は adenocarcinoma in situ (AIS) と診断すべきであるというコンセンサスが得られ つつある。現段階で議論されている内容をこの国際会議を reviewしながら紹介する。

\section{〈略歴〉}

昭和 57 年

筑波大学医学専門学群卒業

昭和59年 国立がんセンター研究所病理部

平成 8 年 平成12年 筑波大学基礎医学系病理学 (診断病理学) 教授 平成16年 筑波大学附属病院病理部長 平成19年 筑波大学大学院人間総合科学研究科 (診断病理学) 教授 筑波大学附属病院つくばヒト組織診断センター(THDC) 部長 


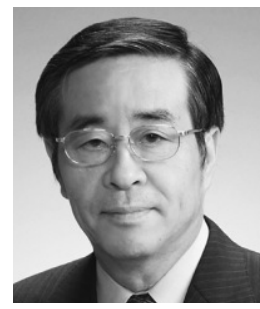

日本医科大学付属病院 病理部 土屋 眞一

最近の乳癌診療には多種多様の病理学的事項が深く係わっている.たとえば病理医は診断に当たって, 1. 組 織型診断，2. 非浸潤癌の診断，3. 波及度診断，4. 悪性度診断，5. 切除断端診断，6. 治療効果予測因子， 7 . 術前治療と組織学的効果判定, および8. センチネルリンパ節生検等, 臨床側の治療方針決定に大きく関与する 項目に対応している.

臨床と病理の共通言語としては, 乳癌取扱い規約（日本乳癌学会編）があるが，今年の 9 月に第16版乳癌取 扱い規約が発刊された。とくに前記 1 の組織型診断と 7 の組織学的治療効果判定に少なからぬ変更・追加がな されている. 本講演ではこれらを中心に概説したい.

組織型診断については，良性腫瘍として「乳管腺腫； ductal adenoma」，「腺筋上皮腫； adenomyoepithelioma」が, 特殊型乳癌には「浸潤性微小乳頭癌; invasive micropapillary carcinoma -produsing carcinoma」が, 腫瘍様病変には「乳腺線維症; fibrous disease」の組織型が新たに採用された。 また, 組織型説明文に関しては, 非浸潤癌, 乳頭腺管癌, アポクリン癌, 線維腺腫, 乳腺症の解説が変更・追 加された。たとえば, 線維腺腫には第15版の「管内型」, 「管周囲型」に加えて, 「類臟器型; organoid type」,

「乳腺症型; mastopathic type」が追加されている。とくに「乳腺症型」は良性病変でありながら画像, 細胞 診で悪性と間違えやすい組織型の代表的なものの 1 つである.

次に, 組織学的効果判定基準に関して, 通常その治療効果判定は術後 5 年あるいは 10 年の予後評価によって なされるが，経過観察時間が非常に長いという難点がある．そこで治療に対する感受性予知指標を同定するた めに薬物療法前の針生検と療法後の手術検体との比較が求められるようになって来ている.術前薬物療法の適 応についての病理側の大きな役目は, 存在する腫瘍が浸潤癌か非浸潤癌かを診断することにある.もう1つは, 浸潤巣の腫瘍内に占める割合で，ほとんどが乳管内癌で浸潤がごく一部に留まる症例は適応にはならない。し たがって，術前薬物療法にあたっては間質に浸潤する径評価が非常に重要であるといえる．次に治療効果判定 については，手術検体からなるべく多数の病理標本を作成することが重要で，不十分な標本作成では正確な判 定、とくに pCR (pathological complete response)の判定は困難である. 診断基準の要点は癌細胞の変性・壊 死・線維化が癌巣全体からみてどの程度の面積を占めているかである。第16版乳癌取扱い規約の新判定基準は, (1) Grade 2 を $2 \mathrm{a}$ と $2 \mathrm{~b}$ に分け, Grade 3 に近い変化を $2 \mathrm{~b}$ と評価する. (2) pCR と Grade 3 との関係を明らか にする. (3) 乳管内成分の取扱いを明確化にする. (4) 乳管内成分とリンパ節転移についてはその変化について は評価せず，有無のみを記載するなど，臨床側に対してより詳細に治療効果判定を伝達できるようになって来 ている.

〈略歴〉

学 歴

昭和 50 年 7 月 日本医科大学卒業

昭和 55 年 4 月 日本医科大学大学院医学研究科卒業 
学 位

学位名: 医学博士 授与大学名: 日本医科大学

取得年月日：昭和55年 4 月 11 日

資 格

厚生省認定死体解剖資格（第3605号）

日本臨床細胞学会認定細胞診指導医（第353号）

日本病理学会病理専門医（第847号）

日本臨床病理学会認定臨床検査医（第452号）

職 歴

\begin{tabular}{|c|c|c|}
\hline 昭和51年 4 月 & 日本医科大学第二病理学教室 医 & 員 \\
\hline 昭和55年 4 月 & 埼玉県立がんセンター病理部 & 点 \\
\hline 昭和58年 4 月 & 埼玉県立がんセンター退職 & \\
\hline 昭和58年 5 月 & 長野県がん検診・救急センター & 検査部 \\
\hline 平成 7 年 4 月 & 長野県がん検診・救急センター & 検査部 \\
\hline 平成11年 9 月 & 信州大学医学部＼cjkstart臨床教授（兼） & \\
\hline 平成12年 4 月 & 昭和大学医学部＼cjkstart客員教授（兼） & \\
\hline 平成15年 4 月 & 長野県がん検診・救急センター & 退職 \\
\hline 平成15年 5 月 & $\begin{array}{c}\text { 日本医科大学付属病院 病理部 } \\
\text { 現在に至る。 }\end{array}$ & 教授 \\
\hline
\end{tabular}

その他

1. 所属学会

日本臨床細胞学会 (理事), 日本病理学会 (評議員), 日本乳癌学会 (評議員, 規約委員, 編集委員, 保険 診療委員), 日本臨床電子顕微鏡学会, 日本癌学会, 日本外科学会, 日本臨床外科学会会員 他

2. Pathology International, Breast Cancer, 日本臨床細胞学会雑誌編集委員 


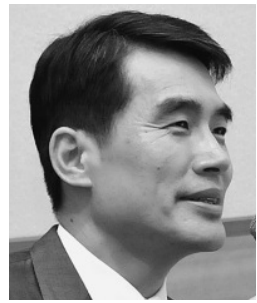

東京都老人総合研究所 老年病のゲノム解析研究チーム 田久保 海誉

バレット（Norman R. Barrett 1903-1979 ロンドンのセントトーマス病院の外科医）がバレット食道を胸 腔内にある胃として報告したのは1950年です。しかし、アリソン (Philip R. Allison 1907-1974 オックスフ オード大学教授）が1953年に胃粘膜におおわれた食道と訂正しています。1952年には、すでにバレット食道に 発生した腺癌の報告があり、食道の原発性腺癌の発生母地として注目されています。しかし、日本国内の食道 の原発性悪性腫瘍の $94 \%$ は扁平上皮癌であり、腺癌を含むその他の癌はまれです（日本食道学会ホームページ http：//esophagus.jp/)。一方、バレット食道の原因とされる胃食道逆流症（GERD）の頻度の上昇は報告さ れているものの、GERD に起因するバレット食道や、バレット食道を発生母地とする腺癌の発生頻度の上昇は 国内では十分に証明されていません。一方、北米やヨーロッパなどでは、白人における食道原発性腺癌の発生 頻度は、扁平上皮癌のそれを大きく超えてきています。この原因は不明ですが、扁平上皮癌の頻度の減少によ るのではなく、腺癌の頻度の急激な上昇によります。欧米では全身に発生する癌の発生率が減少傾向にありま すが、食道の原発腺癌の爆発的な増加のために、腺癌の発生母地であるバレット食道に対する関心がきわめて 高く、多くの論文が発表されています。しかし、バレット食道は、国や地域によりその発生頻度、定義や治療 方針が異なります。すでに、ドイツ、オランダからは500例前後の表在バレット食道腺癌の内視鏡的切除術の報 告があり、バレット食道、バレット癌（バレット食道から発生した癌）の一連の疾患の病理、診断抒よび治療 に関しては、欧米の研究が参考になります。しかし、日本人病理医の立場からは、誤りとすべきものが多くあ り、誤りがドグマ化しているものもあります。今回の特別講演では、1. 食道胃接合部の定義(柵状血管下端と 胃粘膜ヒダの上端) と組織像、2.日本、米国、ドイツ、英国 (英国消化器病学会ホームページ http：//www. bsg.org.uk/) におけるバレット食道の定義、3. バレット食道の病理 (肉眼的、組織学的)、4. バレット食道 の診断 (内視鏡学的、病理学的)、5. バレット粘膜のその他の化生性変化 (気道上皮化生、膵化生)、6. バレ ット癌の組織学的診断基準 (欧米との差異、dysplasia とは何か)、7. バレット癌の発生母地 (本当に特殊円柱 上皮といわれる腸型粘膜か）について、講演者の留学経験と多くの国際学会での見聞をもとに、最新の文献を レビューしてお話します。

〈略歴〉

1975年 7 月 1 日 日本医科大学卒業、日本医科大学第 1 外科学教室特別研究生

1976年 5 月 1 日 埼玉県立がんセンター研究所病理部医員、医長

1991年 4 月 1 日 東京都老人医療センター臨床病理科長

1994年12月から1995年 4 月 Visiting Professor, Department of Pathology, University of Auckland School of Medicine, Auckland, New Zealand

1995年 7 月 1 日 東京都老人総合研究所臨床病理部門 部門長、研究部長

2004年 4 月 1 日 東京医科歯科大学医学部臨床教授

2005年 4 月 1 日 東京都老人総合研究所老年病のゲノム解析研究チーム チームリーダー 現在に至る 
第62回日本食道学会学術集会会長 (2008)、理事、病理分類委員等

International Society for Diseases of the Esophagus (Governor)

World Organization for Specialized Studies on Diseases of the Esophagus (Permanent Scientific Committee Member, Steering Committee Member) 他 


\section{肝胆膵みられる「似て非なる病変」 \\ ・・・午の病理形態学像と臨床病理学的差異について}

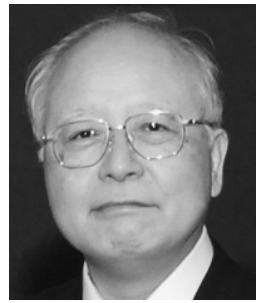

昭和大学医学部第一病理学教室 諸星 利男

肝胆膵は解剖学的・生理学的に別個の臟器ですが、発生学的には同系で、いずれも前腸由来であり内胚葉性 上皮で覆われています。解剖・生理学的見地からは当然かも知れませんが、発生学的立場のみから言えば、こ れら臟器に併発する病変は、各の臟器を越えて系統的に発症し、またより類似した病態を示しても良かろうと 思いますが、実際はそこに発症する疾患の病態像はかなり乘離しています。腫瘍を例にすると、肝胆膵におけ る最も発生頻度の高い腫瘍はそれぞれ肝細胞癌、腺癌、膵管癌であり、前 2 者においては臟器の主たる構成細 胞に由来しているからであると理解されています。しかし、膵臟では膵管癌が最も頻度が高く、主たる構成細 胞である腺房細胞に由来する膵腺房細胞癌はきわめて希です。一方で同系臓器でありますから、当然類似した 組織像を示す一群の病変も存在します。例えば導管上皮に由来する腫瘍、具体的には肝内胆管癌、胆道癌、膵 管癌や囊胞性腫瘍などは、臨床病理像は異なるものの、いずれもほとんど同一の組織像を示します。実際、顕 微鏡的観察のみでは原発臟器の判断が難しい「近似病変」であり、特に膵頭部・膵内胆管周囲の病変は病理医 泣かせの一つとなっております。

炎症性病変に関しては、より多くの内因・外因が関与していることもあり、それぞれ多彩で藏器特異性の高 い臨床病理像を示します。病因からみても、肝に関してはVirus 感染症が最も頻度が高く、膵では Acohol の 多飲ですが、後者は国際的観点からも肝胆膵共通・最大の病因となっています。発症機序から観ますと、肝胆 では実質細胞への直接的障害が問題となりますが、膵に関しては膵液による自己消化が直接的な問題となりま す。また、肝実質細胞や肝胆膵導管上皮は再生能が高度ですが、腺房細胞はほとんど再生しません。このよう な様々な因子が相互作用する結果、肝胆膵に認められる炎症性病変は臓器ごとにかなり特異的な臨床病理像を 示します。一方、最近、話題となっている一群の病変、即ち原発性胆汁性肝硬変 (PBC) や自己免疫性肝炎、 原発性硬化性胆管炎 (PSC)、自己免疫性膵炎 (AIP) なども興味深い臨床病理像を示します。これらはそれぞ れ異なった臨床病理像を示しますが、何れも自己免疫学的機序が関与していると考元られています。しかし、 病理形態学的にはかなり類似した組織像を示しており、「似て非なる病変」を形成しています。以上のように、 肝胆膵各臟器に発症する疾患の臨床病理学的相違は、発生学的、生理・解剖学的理由のみでなく、発生・発育 から死に至るまで経時的に加わった多数の病因が蓄積され反映された結果であると理解されます。

今回、機会を与えられましたので病理形態学的立場から、肝胆膵に認められる幾つかの「近似病変」あるい は「似て非なる病変」について、即ち腫瘍性病変として腺腫一腺癌連鎖（Adenoma-Carcinoma Sequence） を示す肝胆膵の粘液性囊胞腫瘍と高齢者に好発する膵管内腫瘍（Intraductal Tumor）例などを、また炎症性 病変に関連して PBC、PSC、AIP 例などの病理形態学像を提示し、臨床病理学的考察を試みるつもりでおりま す。 
〈略歷〉

学 歴昭和 41 年 3 月 神奈川県立平塚江南高校卒業

昭和 41 年 4 月 昭和大学医学部入学

昭和 47 年 3 月 昭和大学医学部卒業

昭和 47 年 4 月 昭和大学大学院医学研究科病理系第一病理学入学

昭和51年 3 月 昭和大学大学院医学研究科病理系第一病理学修了

国家試験 昭和47年 6 月27日 第53回 医師 国家試験合格 登録第215601号

学 位 昭和52年 4 月 昭和大学 医学博士 甲第 328 号

認定病理医 昭和56年 2 月 認定病理医試験合格 登録 第806 号

職 歴 昭和51年 4 月 昭和大学医学部第一病理学教室助手

(研究歴) 昭和53年 4 月同講師

昭和 54 年10月 西ドイツハンブルグ大学病理学教室助手

(昭和56年 9 月まで兼任)

昭和 60 年 4 月 昭和大学医学部第一病理学教室助教授

平成 7 年11月 昭和大学医学部第一病理学教室教授

平成 7 年11月 秋田大学医学部第二病理学教室兼任講師

平成14年 4 月 昭和大学医学部学生部長

平成14年 1 月 国際病理アカデミー日本支部会長

平成16年 4 月 昭和大学学生部長

平成17年 4 月 昭和大学評議員現在に至る

研究内容：消化器病の病理、特に膵腫瘍、急性・慢性膵炎について 


\section{「外科医のための最新病理学」一下部消化管}

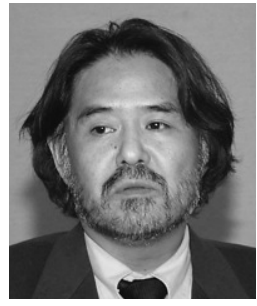

新潟大学大学院医歯学総合研究科分子・診断病理学分野 味岡 洋一

大腸癌の病理診断に関わる最近の知見として、(1) 癌の組織発生、(2) SM 癌のリンパ節転移危険因子、(3) リンパ節微小転移、について概説する。

(1) 癌の組織発生： 大腸癌の組織発生には、adenoma-carcinoma sequence と de novo 発癌が知られてい るが、近年 sessile serrated adenoma（SSA）と呼称される病変が、MSI（遺伝子不安定性）陽性右側大腸癌 の前駆病変として注目されるようになってきた。SSA は従来の病理診断では hyperplastic polyp (HP) とされ てきたが、増殖帯異常や腺管拡張などの構造異型を示し、10 $\mathrm{mm}$ 以上の大きなものが多い。欧米では、右側発 生の SSA は内視鏡的摘除または外科切除を考慮するという治療方針も提起されている。しかし SSA の癌化率 や右側大腸癌に占める SSA 由来癌の頻度についてのデーターはなく、SSA の病理診断基準（HP との鑑別基 準）も必ずしも明確ではない。これらのことは、今後の病理学的検討課題である。

(2) SM 癌のリンパ節転移危険因子：SM 癌は外科治療と内科的治療（内視鏡的切除）の狭間に位置する病 変である。2005年度版大腸癌治療ガイドラインでは、内視鏡的切除 SM 癌のリンパ節転移危険因子として、組 織型低分化、脈管侵襲陽性、SM 垂直浸潤距離 $1000 \mu \mathrm{m}$ 以上、を挙げ、これらのいずれかが認められる場合は追 加外科切除を考慮する、としている。ガイドライン改訂版では「簇出」が新たなリンパ節転移危険因子として 取り上げられる予定である。大腸癌研究会の簇出検討プロジェクト研究では、「簇出」を「癌発育先進部で、単 個または 5 個未満の構成細胞からなる癌胞巣」(Ueno H, et al，2004）と定義し、その程度を $20 \times 10$ 倍視野観 察下、Grade 1 ( $0 \sim 4$ 個)、Grade 2 (5〜9個)、Grade 3 (10個以上)に分けて検討した結果、Grade 1 と Grade $2 / 3$ との間にはリンパ節転移率に有意差があり、Grade 1 を low grade、Grade $2 / 3$ を high grade とすると、high grade は SM 癌のリンパ節転移予測独立因子であると結論付けている。HE 標本による「簇出」 の判定には客観性や再現性に問題が残るが、サイトケラチンCAM5.2免疫染色を用いた演者らの検討でも、簇 出とリンパ節転移との間には有意な相関が示されている。

(3) リンパ節微小転移：リンパ節節微小転移の定義には変遷があり、2002年の TNM 分類第 6 版では、従来 の微小転移は ITC (isolated tumor cell) として、単個の癌細胞または大きさ $0.2 \mathrm{~mm}$ 以下の微小癌巣として位 置づけられるようになった。しかしITC の大腸癌における臨床的意義については明らかにされていない。大腸 癌研究会プロジェクト研究では、ITCについて多施設データーの集計を行っているが、進行大腸癌を用いた演 者らの preliminary study では、ITC 陽性リンパ節が 3 個以上のものは 2 個以下のものに比べ有意に予後不良 であった。今後、ルーチンの病理診断に、ITC 同定のための免疫組織学的検索を導入する必要も考慮される。

〈略歴〉

昭和 59 年

新潟大学医学部卒業

新潟大学大学院医学専攻科入学

(専攻：病理学、所属：病理学第一講座)

昭和63年同 大学院修了 
新潟大学医学部附属病院病理部 医員

平成 2 年新潟大学医学部病理学第一講座 助手

同国立がんセンター研究所病理部研修

平成 5 年新潟大学医学部病理学第一講座 講師

平成 7 年同 助教授

平成 7 年〜 9 年 オークランド大学 (ニュージーランド) 病理学教室留学

平成 14 年 $\sim 17$ 年 新潟大学大学院医歯学総合研究科 助教授

分子細胞医学専攻 細胞機能講座 分子・病態病理学分野

平成17年～新潟大学大学院医歯学総合研究科 教授

分子細胞医学専攻 遺伝子制御講座 分子・診断病理学分野 


\section{甲状腺、副甲状腺、副腎疾患の最新画像診断法}

1)財団法人癌研究会 癌研有明病院 超音波検查部 - 画像診断部 2)財団法人癌研究会癌研有明病院画像診断部 3)財団法人癌研究会 癌研有明病院 核医学部 - 画像診断部

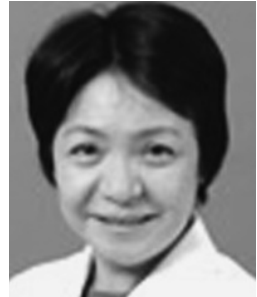

山田 恵子1) 田中宏子2) 小山 真道 ${ }^{3}$ 藤原 良将 ${ }^{11}$ 山本 弥生 ${ }^{2)}$ 行澤 斉悟2) 植野 映子 2 ) 五味 直哉 2 (2) 松枝 清 ${ }^{2}$ 河野 敦 ${ }^{2)}$

内分泌㵴器は生体が個体の維持や種の保存を行うための化学的細胞間情報伝達物資 (ホルモン) を分泌する。 内分泌臟器は全身に存在するが、一般に内分泌外科では甲状腺、副甲状腺、副腎、膵腸管内分泌組織などが扱 われる。本講演では甲状腺、副甲状腺、副腎疾患の最新の画像診断法について述べる。

外科的治療の対象となる甲状腺結節性病変の診断にはまず超音波検查を行う。質的診断には超音波ガイド下 穿刺吸引細胞診を行う。手術方針決定のためには原発巣の位置や浸潤範囲、リンパ節転移の範囲、合併病変の 診断が必要である。局所進展の診断には CT や MRI、遠隔転移の診断には CT や核医学検查が有用である。

副甲状腺腺腫や過形成などの局在診断には超音波検査と $99 \mathrm{mT}$ Tc-MIBI シンチグラフィーがもつとも有用で ある。異所性 (主に縱隔) 病変の検索や、超音波検查と $99 \mathrm{mTc}-\mathrm{MIBI}$ シンチグラフィーの結果が一致しない場 合には CT・MRI を行う。原発性副甲状腺機能九進症においては、副甲状腺病変の術前局在診断と術中 PTH 測定を行うことで、低侵襲手術が可能となる。副甲状腺病変の経皮的エ夕ノール注入療法は通常続発性副甲状 腺機能六進症に対して行われるが、原発性副甲状腺機能六進症においても手術不能例や再手術で合併症のリス クが高い場合などに用いられる。

内分泌学的異常を示す副腎病変の診断には CT や MRI と共に核医学検查が有用である。原発性アルドステ ロン症や Cushing 症候群では I-131-アドステロール副腎皮質シンチグラフィー、副腎髄質褐色細胞腫では I131-MIBG シンチグラフィーが用いられる。また、副腎腫瘤の質的診断には PET-CT も有用である。

さらに本講演では、甲状腺および副腎の偶発腫瘍や、2 2 以上の内分泌臟器に腫瘍が発生する遺伝疾患であ る多発性内分泌腺腫症（MEN）について述べたい。

〈略歴〉

1978. 3 月 東京女子医科大学卒業

4 月 東京女子医科大学放射線医学教室入局

1987. 5 月 癌研究会附属病院放射線科

2005. 3 月 癌研究会有明病院超音波検查部長 (画像診断部副部長兼務) 


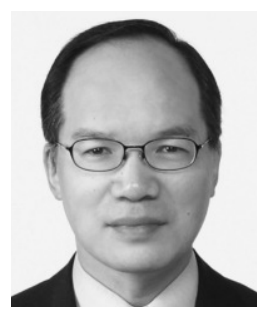

国立がんセンター中央病院 放射線診断部 楠本 昌彦

マルチスライス CT（MD-CT：Multi row Detector CT）は、従来装置に比べてより薄いスライス厚の画 像をより高速に撮像することが可能で、今やわが国では CT 装置の主流となっている。この MD-CT の肺癌の 診断への応用について概説する。

(1)肺小結節の診断

胸部 CT でスクリーニングすると小結節が見つかることは、日常診療でよく経験される。CT で見つかる 1 $\mathrm{cm}$ 未満の肺小結節は、肉芽腫や肺内リンパ節の可能性が高い。特に肺内リンパ節は下葉の胸膜直下から近傍に みられ、高分解能 CT で境界明瞭な小結節なことが多い。また連続した薄層 CT の縱隔条件をよく観察すると 小石灰化が描出されることもあり肉芽腫の診断には有用である。

結節の辺縁がスピクラや分葉状を示す場合は肺癌を示唆する古典的な画像所見である。それ以外に有用なの は薄層 CT ですりガラス状の辺緑を持つ場合で, 肺胞上皮置換型の進展部を有する高分化腺癌である可能性が 高い。さらにこれらの腺癌が一定の大きさを持つと、内部の充実部分にはエアブロンコグラムを有し、血管集 中像や胸膜陥入像も見られるようになり、診断に有用である。

(2)肺門、縦隔リンパ節の転移診断

手術適応の決定、および術式の決定に縦隔、肺門リンパ節転移診断は欠かせない画像情報である。縦隔リン パ節転移診断の基準は短径 $1 \mathrm{~cm}$ 以上という大きさによる診断が長らく用いられているが、その正診率には限 界があり部位別の考え方や縦隔鏡の適応など柔軟性が必要である。MD-CTによる造影 CT では、従来 CT に 比べて肺門リンパ節の細かい形状診断に適している。特に11番の葉間リンパ節の節外転移の術前診断が重要 で、これらの診断には連続した造影剤を用いた連続した薄層 CT が診断に役立つ。

(3)胸膜播腫の診断

MD-CT では、薄いスライス厚の CT を連続して広範囲で撮像できるため、胸膜播腫の診断には適している。 主腫瘍が胸膜に連続する場合、原発巣を含んで広い範囲で連続した薄層 CT 画像を再構成し、胸膜上に複数の 小結節を認めた場合は胸膜播腫である可能性が高い。通常、胸壁胸膜面よりも葉間胸膜面の方が播種の微小結 節の描出が良好である。画像で胸膜播腫が疑われた場合は、開胸術に先立って審查胸腔鏡を先行させて確定診 断を行うことで無駄な開胸術の省略に寄与する。

〈略歴〉

\section{【学歴】}

昭和 61 年 3 月 神戸大学医学部卒業

平成 4 年 3 月 神戸大学大学院医学研究科修了

\section{【職歴】}

昭和61年 7 月 神戸大学医学部附属病院放射線科 医員 
研修医、医員、助手を経て、

平成10年 7 月 国立がんセンター中央病院 放射線診断部 医員

平成14年 4 月 国立がんセンター中央病院から同医長

現在に至る

\section{【非常勤職】}

平成14年 4 月から 島根大学医学部非常勤講師

平成15年 4 月から 神戸大学医学部非常勤講師ならびに臨床助教授

\section{【政府系委員】}

平成18年 3 月より 環境省中央環境審議会 石綿健康被害判定部会専門委員 


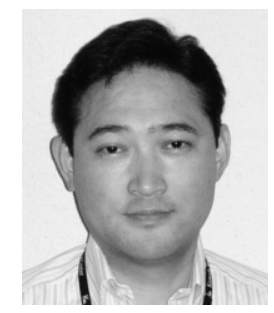

亀田メディカルセンター 乳腺センター・乳腺科 戸崎 光宏

乳腺画像診断は近年も著しい進歩を続けている.マンモグラフィではデジタル化が急速に進み, さらに tomosynthesis の臨床応用が海外で盛んに行われている. 従来のマンモグラフィの最大の欠点である画像の重 なりを解決する大きな技術革新である. 超音波検査では B-mode, 血流画像, エラストグラフィがルーチンで 行われており, 複数の画像情報を加味して診療しなくてはならない現状にある.また, 乳房自動スキャンの商 品化の可能性により, 超音波乳癌検診の方向性が将来大きく変わることが指摘されている.乳房 MRIでは画質 の向上に様々な技術が投入され高画質 MRI が一般化している。そして MRI の普及により MRI だけでしか検 出できない乳癌が, 本邦でもやっと報告される様になり, MRI ガイド下生検をせざるを得ない状況に直面して いる。 また，拡散強調画像は海外をリードする形で本邦に扔いて普及しており，その臨床的意義が放射線科領 域で数年にわたり議論されている。ささに，MRスペクトルスコピーの登場により，これまで知り得ることが できなかった分子情報が報告される様になってきた。術前化学療法の早期効果判定においてルーチン化する可 能性も指摘されている。核医学領域では PET, PET-CT の有用性が多く報告されてきている. 単なる staging 目的の有用性だけでなく, 乳癌の molecular imaging としての FDG-PET の特徴が討論されている.

本邦ではマンモグラフィ, B-mode 超音波抒よび画像ガイド下生検を外科医中心で行ってきたが，そのため 学術的には海外から大きく遅れをとったことは事実である. 画像診断医の乳腺領域への無関心とマンパワー不 足が大きな原因であった。しかし，このような最新画像を外科医が全て熟知することは不可能である。今後は， 乳腺専門の画像診断医を早急に育成し, 進歩し続ける画像情報を詳細に検討し, 新たな知見を見いだしていく ことが必要である。特に乳腺診療はチーム医療が必須であり, 外科医にとってこれらの画像を熟知した画像診 断医と密に連携をとることが理想である.

今回の発表では、すべての modality をカバーすることは不可能であるため, MRI を中心に解説したい. 特 に, 診断機器の技術面の詳細は割愛し, 乳腺外科医に役立つ最新画像の「臨床的」意義を提供したい.

\section{〈略歷〉}

平成 5 年

東京慈恵会医科大学卒業

平成 5 年

東京都立駒込病院 外科研修

平成 7 年

東京慈恵会医科大学 放射線科助手

平成 10 年

東京都立駒込病院 病理科 国内留学

平成11年

東京慈恵会医科大学 放射線科助手

平成17年

ドイツイエナ大学 放射線科 留学

平成18年 4 月

亀田総合病院 乳腺科 部長代理

平成19年 6 月

亀田総合病院 乳腺科 部長

平成18年 4 月加ら 東京慈恵会医科大学 放射線科 非常勤講師 兼務 
乳腺画像診断（特に画像と病理との対比）および MRI ガイド下生検

著書

「乳腺 MRI 実践ガイドー撮像法, 読影基準, 治療一」文光堂 


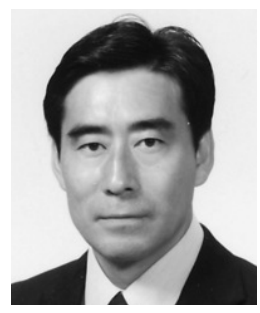

東海大学医学部 基盤診療学系画像診断学 今井 裕

近年の画像診断装置の進歩は、微細な所見が問題となる消化管診断においてもその応用範囲を広げ、これま で知ることが出来なかった病態を描出するようになった。X 線造影検査では、空間分解能の極めて高い平面検

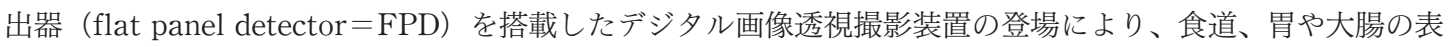
在型（０型）、とくに表面型（０ＩI 型）の描出が容易になった。とくに食道の表面癌（II a ～II c 型）では、 連続撮影により造影剤の付着が適切な時期で撮影することができるようになり、深達度 T1a の表面平坦ある いは陥凹型の表在癌も陰影斑としてきちんと描出でき、さらに内視鏡では所見を客観的に捉えにくい僅かな食 道壁の変形も診断される。これらの進歩により、治療法の選択に必要な腫瘍の浸潤範囲と深達度診断を明確に 示すことができるようになった。

最近のマルチスライス CT の進歩には、2つの方向性があり、一つは検出器の多列化で、現在では最大 320 列 の検出器を搭載する装置も稼働している。もう一つの新しい流れは、dual energy という低電圧と高電圧の異 なるコントラストの画像をほほ同時に撮像し、各物質のX 線吸収による違いをより詳細に解析できるように なったことである。消化管の診断においては、最近急速に普及している64列のマルチスライス CT 用いた CT colonography が多くの施設で試行され、学会等ではトレーニング講座も開催されている。これによりこれまで 診断が難しいとされていた大腸表面型腫瘍も診断できることが少しずつ分かってきた。また、多くの種類の表 示方法が応用されるようになり、これまでの任意多断面再構成 (multi-planer reconstruction=MPR)、注腸 モード (air image)、内腔表示 (virtual endoscopy) のほかに腸管を切り開いたような表示である展開像 (virtual gross pathology) なども使用されている。また、前処置法も色々と工夫され、従来の腸管洗浄液のみでは水没 した領域の粘膜面の観察が出来なかったのに対し、陽性の経口造影剤を併用することにより水没した粘膜面も 診断しようとする electronic cleansing やfecal tagging と呼ばれる技術も試行されている。また、コンピュ

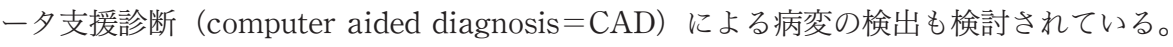

MRI は、軟部組織のコントラスト分解能に優れているという利点に、空間分解能を補うことにより腫瘍の壁 内深達度診断が可能になった。空間分解能を向上させる方法としては、体腔内コイル、体表に置く多素子から なる RF コイル (phased array coil)、あるいは強い信号雑音比の得られる高磁場装置である3T MRI などが 挙げられる。直腸癌の診断においては、T2強調像にて粘膜層、粘膜下層、固有筋層、周囲脂肪織を識別して描 出することができ、結果として腫瘍の壁内浸潤を診断することが可能になった。また、リンパ節転移の診断に 関しては、最近学会等で注目されている拡散強調像を用いた検討が行われている。しかしながら、リンパ節転 移の有無が予後を左右する食道癌での検討では、感度、特異度ともまだ低く、今後の大きな課題である。一方、 大腸癌自身の検出にも、拡散強調像を用いた多施設共同研究が行われており、その中間報告では腫瘍の大きさ が $2 \mathrm{~cm}$ 以上であれば感度、特異度とも高いと言える。 
慶應義塾大学医学部 卒業

1978年 4 月

慶應義塾大学医学部放射線科 入局

1988年-1989年

米国ペンシルヴァニア大学医学部放射線科に訪問講師として留学

1995年-1999年 8 月

国家公務員共済組合連合会 立川病院放射線科部長

1999年 9 月

2001年 6 月

慶應義塾大学医学部放射線科学教室講師に就任

2004年 4 月

東海大学医学部総合診療学系放射線科学教授に就任

2006年 4 月

東海大学医学部付属病院副院長に就任

東海大学医学部副学部長に就任

専門領域

腹部放射線診断、とくに消化器および泌尿器領域 
消化器実質臟器の画像診断は超音波および今回の講演の中心となる CT の出現を端緒として実際に始まっ たと言っても過言ではなく、これらの機器によりそれまでの間接的な画像診断から病変そのものを描出できる 直接的診断が可能となった。少し遅れて MRI がこれに続き、この三種類でその他のモダリティーを現在まで圧 倒しているのが現状である。

当初は先に述べたごとく存在診断、形態診断に留まっており、造影剤もよりよいコントラストを得ることが 主要な使用目的であり、病変の血流情報を得ることは、一部のダイナミック検查を除いて難しいものであった。

現在では存在、形態診断、血流診断、さらには機能診断といったより良質な画像診断を行うため、様々な工 夫が行われるようになってきている。

一見、華々しい最新の放射線医療機器の発展に目を奪われてしまい勝ちであるが、ハードの発展のみならず それを利用する医師の側の創意工夫、病変の性状に着目したさまざまな試行錯誤によって画像診断の改良、病 変の解明が行われてきた点は意外と軽視されがちである。

そういった工夫で重要な位置を占めているのは、病変の血流動態を画像に反映させることを試みた造影剤の 使用方法である。またそれの実現には機器の高速化も必要であり、その延長に現在のマルチスライス CTとそ の高速撮像を利用し造影相を多相に得ることによる病変の診断がある。

さらに血流動態のみならず、機能的側面を画像に反映させ良質な診断に寄与しょうという試みがなされてい る。ここで言う機能とは、肝細胞の造影剤取り込みのことである。それは主として肝腫瘍の診断において、MRI の肝細胞特異性を有する造影剤による腫瘍の質的診断を指す。現在盛んに多くの検討がなされているところで ある。

さらに、形態診断にもへリカル CT の登場以降大きな波が訪れた。それは三次元画像である。三次元画像は、 あくまでも断面の連続であった CT P MRI 画像を立体的に把握できるよう構成され、実際に病変を目にしつ つ治療を行う多くの臨床医に有用と考えられる。しかしながらその限界も多く指摘されるところで、MPR 像を 加えた診断、三次元画像に動きをつけた画像などの多くの試みがなされている。

放射線医療機器の分野では、3T の MRI、256列のヘリカル CT、320列のマルチスライス CT の出現が相次ぎ、 それらが作り出す新しい画像には目を見張るばかりではある。しかしながら、これらのすばらしい機器の能力 を生かし、臨床に還元するのは多くの医師の人間臭い工夫の積み重ねが欠かせない。さらにその工夫を生み出 すのは、外科医をはじめとする臨床医の側からの積極的なニードであることを忘れてはならない。 以上

〈略歴〉

昭和 61 年 日本医科大学卒 同付属病院研修医

昭和63年 国立がんセンター病院放射線診断部レジデント 
平成 3 年 日本医科大学付属病院放射線科助手

平成12年 日本医科大学多摩永山病院放射線科助教授

平成19年 日本医科大学武蔵小杉病院放射線科准教授

現在に至る 


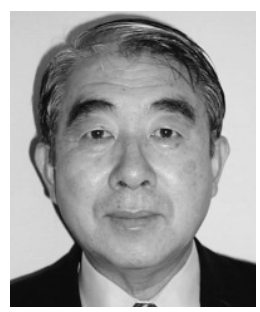

日本臨床外科学会・名誉会員、帝京大学医学部名誉教授・客員教授、京浜総合病院外科

山川 達郎

近年の内視鏡治療ならびに内視鏡外科手術の進歩には、実に目を見張るものがある。内視鏡治療の面では、 以前から行われてきた消化管の狭窄解除術あるいは内視鏡下乳頭切開術に始まる胆道疾患の治療に加え、最近 は、早期食道、胃、大腸癌のあるものに対して、内視鏡下粘膜/粘膜下層切除術 (Endoscopic Mucosal Resection/ Submucosal Dissection； EMR/ESD) が行われるようになり注目をあびている。一方、内視鏡外科手術は、 開腹術と同等のリンパ節郭清が技術的にも可能であると評価されるに至り、胃癌、大腸癌、食道癌をはじめ、 肝臓癌、膵臓癌の手術にまで応用され、さらに内視鏡下胃切除術あるいは胃空腸バイパス手術や内視鏡下調節 性胃バンディング術 Laparoscopic Adjustable Gastric Banding 法などともに肥満症患者の治療法としても定 着しつつあり、手術症例数は増加の一途をたどっている。また最近は、正常な消化管壁あるいは䐋壁を切開し、 そこから内視鏡を腹腔内に挿入して虫垂切除術、卵管結紮、胆囊摘出術、脾臟摘出術を行う Natural Orifice Trans-luminal Endoscopic Surgery（NOTES）といった新しい手術法が開発され、注目をあびている。

何故にこれらの術式が、臨床に受け入れられたのだろうか。共通点は共に低侵襲性であって、術後のQOLの 向上に貢献する術式であることであるが、このような手術術式が可能となった主因は、機器の開発と改良によ つて切離法ある吻合法に革新的な進歩がもたらされた結果であるということに帰着する。すなわちこの変革 は、手術の基本である腸管切離法あるいは縫合法がより信頼のおける機器に委ねられるようになったためであ つて、確立された開腹手術とは、原則を異にする異質の手術術式が臨床に登場したわけではない。

しかしながら、その一方で、術式の選択枝が多岐にわたり、戸惑うこともしばしばである。治療法の選択に あたっては、流行であるからという興味的な見地から選択すべきではないということは言をまたないことであ るが、内科、外科、内視鏡科など、それぞれ診療科には、それぞれに独自の主張があって、受診科の治療方針 や担当医の技術の有無によって治療法の選択がなされる可能性があることも否定することはできない。したが ってこれからの消化器科・外科・内視鏡医には、各科間の垣根を越えて、各術式の利点と欠点ならびに術中、術 後早期・晚期合併症など短期・長期予後について率直に意見を交換して、最適な治療法を決定する態度が求め られよう。そして、べストと考えられる術式について、自分にその技術がない時には、その治療を専門医に委 ね、また反対に自分がその患者の治療を任せられた場合には、誠心誠意、患者さんのために最善の成果が得ら れるよう努力すべきである。これこそが、また臨床医としてもつべき倫理の原点ではなかろうか。

本講演では、消化器内科医・内視鏡医と共に考えるべき問題について、総胆管結石の治療法の選択に関する 演者の30年にわたる経験から得た私見を交え、考察したい。

〈略歴〉

$1961 ;$ 日本医科大学卒業

1962 1969；インターン修了後、東京大学第 3 外科、1969；学位（東京大学）受領 1969 1972 ; Cedars-Sinai Medical Center 外科留学 
1972 1973；帝京大学第 1 外科講師 $1973 \sim 1981$; 準教授

1981 1986；帝京大学溝口病院外科医長、

1986 2000；帝京大学溝口病院外科教授

2000～；帝京大学医学部名誉教授・客員教授 京浜総合病院顧問・外科

2001 2007 ; National Delegate, ISS/SIC、2005 2007 ; Vice President、ISS/SIC

2001 2007 ; Governor, ACS

2007 2011; Councilor, ISS/SIC

2007～2010；Secretary General／Treasurer； IFSES（世界内視鏡外科学会連盟） 


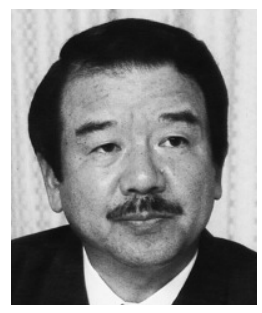

東邦大学名誉教授、東京医療保健大学大学院 炭山 嘉伸

一般的に感染症の診療には、(1)正確な感染症の存在と重症度の認知、(2)問題となる臟器・解剖と病原微生物、 (3)(1)と(2)に基づく適切な治療、(4)効果判定、が基本となる。

外科的感染症の存在は疼痛、発赤、腫脹、熱感といった古典的な “炎症の 4 主徵” 呈する場合が多く、存 在診断は比較的容易である。特に、日本では CT や腹部超音波検查診断技術が進んでおり、極めて正確に診断 可能である。また、重症度の判定には、局所所見とともに、体温、白血球数、CRP、により判定され、集中治 療を要するような重篤な状態では、さらに APACHI II scoreにより判定される。外科感染症の原因となる病原 微生物は、基本的には自らが持つ常在細菌による内因性感染であるが、米国では病院関連型 MRSA の市中感染 や市中型 MRSA の市中感染が問題となっている。幸い、いずれも日本では希であるが今後の動向には注意した い。

外科感染症の治療には、切開排膿という外科的手技の存在が他の領域の感染症と大きく異なる点であり、こ の外科的手法と抗菌薬を組み合わせることが外科感染症治療の基本的手法であるといえる。さらに重症な感染 症、または極めて重篤な状態へ向かいつつある状態では、免疫グロブリン、エンドトキシン吸着、持続的血液 濾過透析、ステロイド薬の投与なども行われる。一方、外科感染症の治療の判定には明確な基準はなく、今後 の検討課題であるといえる。

さて、日本では1980年代の後半から出現した MRSA が契機となり、外科感染症対策、特に、交差感染対策、 而性菌対策、抗菌薬の適正使用が叫ばれるようになってきた。これらは、当初、大病院において問題となって いたが、わが国でも包括医療の導入により、早期退院が促進され、術後感染症例が市中に生活の場を広げてき ている。また、高齢者の増加に伴い、尿路、呼吸器、裖瘡、経腸栄養のための胃瘦、などに MRSA や緑膿菌な どの耐性菌を定着させている患者が増加している。このため、当初、大病院の患者だけが持っている耐性菌が 一般開業医や小規模な診療所でも伝播し、これらの耐性菌による市中感染も増加する危険性があることを強く 認識すべきと考える。

これらの耐性菌の定着を防ぐことは極めて難しいことではあるが、創感染や裖瘡を治癒させることは、耐性 菌の定着をなくし、危険なリザーバーを減少させるための最も確実な方法となる。そのためには、最新の創傷 治癒理論に基づいた創の管理が重要な意味を持つことになる。従来から漫然と行われてきた消毒薬による創傷 部位の消毒とガーゼによる創傷の被覆は、むしろ創傷治癒を障害してきたことが明らかとなった。創傷処置は すでに新しい時代に入っており、具体的には、感染巣に対する化学的デブリードマンとそれに引き続く閉鎖ド レッシングによって速やかに創を治癒させる手法が広まってきている。

従来、大病院中心に考えられてきた外科感染症対策は、今後、第一線の臨床医、医療従事者を通して広く社 会的に推進されるべき事であると考える。 
昭和 45 年 3 月

昭和 56 年 58 年

留 学

昭和56年12月

昭和 58 年 12 月

昭和 62 年 1 月

平成12年～
東邦大学医学部卒業

(1)八ワイ大学・クィーンズメディカルセンター

(2)スタンフォード大学・メディカルセンター

(3)メイヨークリニック

（留学中）東邦大学医学部外科学第三講座講師 東邦大学医学部外科学第三講座助教授 東邦大学医学部外科学第三講座教授 学校法人東邦大学評議員 副医学部長

平成15年 7 月～18年 6 月＼cjkstart東邦大学医療センター大橋病院 病院長 平成 20 年 3 月〜 東邦大学 退職 平成 20 年 4 月～ 東邦大学 名誉教授就任

現 在 学校法人東邦大学 理事・評議員

平成 20 年 5 月末

6 月医療法人 清智会記念病院 名誉院長

\section{公的役職}

厚生労働省＼cjkstart薬事・食品衛生審議会専門委員

川 中央薬事審議会臨時委員

独立行政法人医薬品医療機器総合機構専門委員

厚生労働科学研究（医療技術評価総合研究事業）

学会役職

理事長

副会長

日本外科感染症学会

代表世話人

JNIS 研究会

日本外科真菌症研究会代表世話人

東京消化器外科感染症研究会代表世話人

城南地区周術期管理研究会代表世話人

城南外科侵襲研究会代表世話人

城南緩和医療研究会代表

理事・幹事・監事 日本臨床外科学会常任幹事を含め 15 の理事・監事

評議員

日本外科学会を含め 23 の評議員

世話人

主催学会

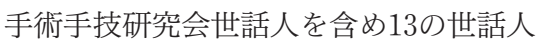

2002年11月18～19日 第24回日本手術医学会総会

2003年 7 月 $16 \sim 18$ 日 第58回日本消化器外科学会総会

2005年12月 $7 \sim 9$ 日 第18回日本内視鏡外科学会総会

2006年 5 月 $10 \sim 12$ 日 第18回日本肝胆膵外科学会総会

他、13学会主催 